\title{
14. MINERALOGY AND COMPOSITIONS OF SELECTED BASALTS FROM DSDP LEG 34
}

\author{
T.E. Bunch, Ames Research Center, NASA, Moffett Field, California \\ and \\ Ron LaBorde, Scripps Institution of Oceanography, University of California, San Diego, \\ La Jolla, California
}

\begin{abstract}
Samples of medium- to fine-grained basalt from Site 319 have been microprobed and bulk analyzed by XRF. Plagioclase is the most common phenocryst and microphenocryst, followed in abundance by augite; fresh olivine is present in only one sample although altered olivine is common. Silica was observed in one sample. Plagioclase phenocrysts cores are $\mathrm{An}_{88-80}$ and are continuously zoned to $\mathrm{An}_{50-20}$ rims. Microphenocrysts and groundmass grains overlap in composition with each other and are continuously zoned with the most sodic varieties reaching $\mathrm{An}_{7}$. Interstitial $\mathrm{K}$-feldspar is present in half of the

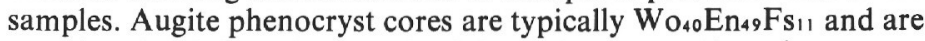
zoned to Fe-rich augite or subcalcic augite rims. Microphenocrysts and groundmass pyroxene are also zoned with microphenocrysts showing increasing $\mathrm{Ca}$ depletion with $\mathrm{Fe}$ enrichment and groundmass grains showing $\mathrm{Ca}$ enrichment with increasing iron. Interstitial pyroxene is mostly ferroaugite.. Olivine is Fo84-81. Titanomagnetite or less common skeletal ilmenite and minor sulphides are also present. The mineralogy and bulk compositions correspond to oceanic ridge tholeiites. Bulk compositions are characterized by low $\mathrm{K}_{2} \mathrm{O}$ (0.05-0.36 wt\%), high $\mathrm{FeO}^{*}$ (8.34-13.30), and moderately low $\mathrm{Al}_{2} \mathrm{O}_{3}$ (13.56-15.79 wt\%). Normative compositions range from olivine to slightly quartz normative if an assumed $\mathrm{Fe}_{2} \mathrm{O}_{3}$ content of $1.5 \mathrm{wt} \%$ is used. Basalts from Site 321 are more fractionated $\left[\mathrm{FeO}^{*} /\left(\mathrm{FeO}^{*}+\mathrm{MgO}\right)=2.15-2.70\right]$ compared with those from Hole 319 (1.10-1.65). All samples appear to have derived from a common parental magma with minor compositional variations consistent with crystal fractionation. Extreme compositional zoning, together with textural features, indicate a rapid cooling history.
\end{abstract}

\section{INTRODUCTION}

This report is essentially a presentation of petrographic observations, electron microprobe analyses, and XRF analyses of samples received for study from Leg 34 . These samples are as follows: 319-13$1,77-80 \mathrm{~cm}$; 319-13-1, 140-143 cm; 319A-1-1, 48-51 cm; 319A-1-1, 78-79 cm; 319A-2-1, 111-114 cm; 319A-3-1, 78-81 cm; 319A-3-1, 80-82* cm; 319A-3-2, 84-86* cm; 319A-3-3, 64-67* cm; 319A-3-5, 75-78 cm; 319A-5-1, 20$22 \mathrm{~cm}$; 319A-6-1, 93-98 cm; 319A-7-1, 121-124 cm; 32114-1, 42-45 cm; 321-14-2, 9-12 cm; 321-14-3, 7-10 cm; and $321-14-4,7-10 \mathrm{~cm}$. An asterisk indicates medium- to coarse-grained samples; all others are fine to medium grained. Descriptions of individual rocks are given at the end of the paper.

The descriptive terms used are those that are in common acceptance today or those that are preferred in the American Geological Institute, "Glossary of Geology," 1972. The terms phenocryst, microphenocryst, and groundmass minerals are used in the common sense. The terms interstitial feldspar and pyroxene refer to extremely small (commonly $<0.02 \mathrm{~mm}$ ) grains that are crystalline and compositionally distinct from or transitional to larger grains. Interstitial feldspar is $\mathrm{K}$ feldspar in composition, and interstitial pyroxene is commonly more Fe rich than larger pyroxene grains and usually does not overlap in composition with groundmass pyroxene, indicating a distinct period of crystallization. Interstitial grains, common to nearly all samples, are the smallest discernible grains with both the microscope and microprobe.

Emphasis is placed on samples from Site 319, particularly Hole 319A, since most of our samples are from this site and we can relate our data somewhat to a sequence of different flow units, although not all of the flow units from Hole 319A are represented by our samples. Our purpose is not to discuss the analytical results and observations in detail, but to present the analytical data with some interpretation and comparison with those of other oceanic basalts. A limited number of samples and the general unavailability of other project investigators' results preclude an application of our data at this time to the overall problems of Leg 34 petrology. 


\section{BULK COMPOSITIONS}

Bulk compositions of fine- to medium-grained rocks from Hole 319 and Site 321 indicate that they are oceanic ridge 01 -tholeiite basalts (Table 1). This conclusion is based on low $\mathrm{K}_{2} \mathrm{O}$ contents $(<0.36 \mathrm{wt} \%)$ and olivine-normative compositions in all but Samples 319$13-1,77-80 \mathrm{~cm}$ and $321-14-1,42-45 \mathrm{~cm}$. Figure 1 shows a normative olivine-plagioclase-pyroxene diagram with $\mathrm{FeO}^{*}$-based analyses that definitely plot on the 01 tholeiite side of the arbitrary 01- and P1-tholeiite boundary of Shido et al., 1971. Recalculation of the normative mineralogy to give $\mathrm{FeO}^{*}+1.50 \% \mathrm{Fe}_{2} \mathrm{O}_{3}$ shifts the original plots into the P1-tholeiite field along the cotectic boundary. This recalculation seems justified based on previous arguments by Coombs (1963) and Kay et al. (1970), although it tends to confuse the issue of nomenclature. The original normative compositions definitely show an olivine-normative characteristic, consistent with abundance of relic olivine in some samples, although other samples show no evidence of olivine crystallization. In many cases petrographic observations argue for a P1-tholeiite classification. Plagioclase in many samples is clearly the first mineral to crystallize. Only one sample was found to contain relic olivine microphenocrysts, although four samples show evidence that larger grains of olivine existed before alteration to smectite. Both pyroxene and plagioclase appear to have crystallized simultaneously in three other samples, and no evidence of any olivine was observed. Alternatively, the assumed value of $1.50 \% \mathrm{Fe}_{2} \mathrm{O}_{3}$ (bulk) may be too high; this will be clarified by wet-chemical analyses that are not presently available.

Assuming that these are 01-tholeiites, a comparison is made graphically in Figure 2 between our samples and those from some other basaltic provinces. The Leg 34 basalts are consistent with those from other oceanic ridge sites. Samples from Site 321 have low normative olivine and are clearly separated from 319A basalts.

Data in Table 1 indicate that the analyses are not greatly different. $\mathrm{SiO}_{2}, \mathrm{MnO}$, and $\mathrm{P}_{2} \mathrm{O}_{5}$ show little variation. $\mathrm{FeO}^{*}$ and $\mathrm{MgO}$ are fairly constant in samples from the same hole and within the same flow unit, with the exception of Samples 319A-1-1, 48-51 cm and 319-13-1, $77-80 \mathrm{~cm}$. The consistency within each suite of samples and the grouping of analyses from different sites are shown in Figure 3. The $\mathrm{FeO}^{*} / \mathrm{MgO}$ ratio is moderately low for Site 319 samples, whereas it is extremely high for those in 321 , which is rare for ocean ridge tholeiites. It would appear from Figure $3 b$ that basalts from Site 321 are more fractionated than the others in view of their high $\mathrm{FeO}^{*} / \mathrm{MgO}$ ratios. Moreover, they are also higher in $\mathrm{TiO}_{2}$ contents (Figure 3a). In contrast, one would expect higher alkali contents than those present in 321 basalts, as shown in Figure 3c. Most of the samples from 319A are higher in total alkali content than those from 321. In addition, petrographic observations indicate that all samples from 319A have interstitial material of Kfeldspar composition or $\mathrm{K}$-rich groundmass glass, whereas samples from 321 have little or no interstitial Kfeldspar. The single analyzed sample from Hole 319 (Sample 13-1, 140-143 cm was not analyzed) has the lowest $\mathrm{FeO}^{*} / \mathrm{MgO}$ ratio and is quite low in both total alkalis and $\mathrm{TiO}_{2}$ compared with all other samples.

\section{SAMPLE DESCRIPTION AND MINERALOGY OF SAMPLES FROM SITE 319}

General sample textural descriptions and mineral compositions are given in this section. Feldspar compositional variations for each sample are shown graphically in Figure 4. Pyroxene compositional trends are shown in Figures 5, 6, 7, and 8. In addition, selected pyroxenes from each sample are given in Table 2 . Titanomagnetite and ilmenite compositions are given in Table 3.

\section{Basalt Unit Sample Descriptions}

Two samples (319A-1-1, 48-51 cm and 319A-1-1, 78$79 \mathrm{~cm}$ ) were studied from the uppermost unit. The 48-57 $\mathrm{cm}$ interval is medium grained ophitic to variolitic, whereas the $78-79 \mathrm{~cm}$ interval is somewhat coarser grained and ophitic. Textural and mineralogical comparison of these two samples indicates that the upper interval crystallized more rapidly than the lower interval, based on the smaller grain size, more abundant skeletal crystals, and larger amounts of poorly crystallized groundmass in the uppermost sample.

Three samples (319A-2-1, 111-114 cm; 319A-3-1, 78$81 \mathrm{~cm}$; and 319A-3-5, 75-78 cm) were studied from the thick 15.6-meter unit. No significant compositional differences were noted between the lower and upper intervals, and the conclusion is made that no significant crystal fractionation occurred. The variable texture and grain size of our samples, regardless of their position within the unit, are puzzling. Textures range from glomeroporphyritic-subophitic at the base through fine grained subophitic-variolitic and coarse grained ophiticdiabasic in the middle portion to porphyritic-holocrystalline in the uppermost interval. Plagioclase core compositions are nearly the same in all samples (An ${ }_{84}-$ $\mathrm{An}_{82}$ ), although pyroxene compositional trends in the coarser grained intervals are different from those of the fine- to medium-grained samples (Figures 5, 6, and 7). Nearly all samples show evidence of rapid cooling in the late stages (fine-grained variolitic textures and skeletal grains of pyroxene and opaque minerals together with patches of devitrified or altered glass)

Single samples from the 12.5- and 10.6-meter units are inadequate to give insight to chemical and textural variations within their respective units.

\section{Mineralogy}

\section{Feldspar}

Major compositional variations in plagioclase in all samples from Site 319 are shown in Figure 4. Nearly all plagioclase grains, regardless of size, are compositionally zoned. The interior two-thirds of most large phenocrysts are fairly homogeneous in composition, whereas the outer one-third is strongly zoned and may show a compositional range as great as $70 \%$ An. All grain sizes of plagioclase are notablv low in $\mathrm{K}_{2} \mathrm{O}$ content, which is consistent with low bulk $\mathrm{K}_{2} \mathrm{O}$. The highest 
TABLE 1

X-Ray Fluorescence Analyses of Fine- and Medium-Grained Basalts From Leg 34

\begin{tabular}{|c|c|c|c|c|c|c|c|}
\hline \multicolumn{8}{|c|}{ Hole 319A Sample (Interval in $\mathrm{cm}$ ) } \\
\hline & $1-1,48-51$ & $2-1,111-114$ & $3-1,78-81$ & $3-5,75-78$ & $5-1,20-22$ & $6-1,93-98$ & $7-1,121-124$ \\
\hline $\mathrm{SiO}_{2}$ & 50.30 & 51.50 & 50.10 & 50.68 & 49.60 & 50.15 & 50.18 \\
\hline $\mathrm{TiO}_{2}$ & 1.17 & 2.03 & 2.05 & 2.00 & 1.87 & 1.87 & 1.79 \\
\hline $\mathrm{Al}_{2} \mathrm{O}_{3}$ & 14.40 & 14.20 & 13.60 & 14.20 & 15.05 & 14.62 & 13.91 \\
\hline $\mathrm{FeO} * \mathrm{a}$ & 9.49 & 10.05 & 10.77 & 10.23 & 10.60 & 10.44 & 10.60 \\
\hline $\mathrm{MgO}$ & 8.30 & 6.10 & 6.60 & 6.50 & 6.63 & 6.40 & 6.47 \\
\hline $\mathrm{CaO}$ & 12.50 & 11.70 & 11.10 & 11.26 & 11.36 & 11.78 & 11.60 \\
\hline $\mathrm{MnO}$ & 0.17 & 0.17 & 0.16 & 0116 & 0.18 & 0.17 & 0.17 \\
\hline $\mathrm{Na}_{2} \mathrm{O}$ & 2.59 & 3.23 & 3.60 & 3.37 & 3.10 & 3.01 & 2.83 \\
\hline $\mathrm{K}_{2} \mathrm{O}$ & 0.05 & 0.27 & 0.12 & 0.11 & 0.30 & 0.36 & 0.19 \\
\hline Total & $\overline{98.97}$ & $\overline{99.15}$ & $\overline{98.10}$ & $\overline{98.51}$ & $\overline{98.69}$ & $\overline{98.79}$ & $\overline{97.74}$ \\
\hline \multicolumn{8}{|c|}{ Normative Composition with $\mathrm{Fe}_{2} \mathrm{O}_{3}=1.5 \mathrm{wt} \%$} \\
\hline $\mathrm{q}$ & - & - & - & - & - & - & - \\
\hline or & 0.30 & 1.62 & 0.73 & 0.67 & 1.80 & 2.17 & 1.16 \\
\hline$a b$ & 23.45 & 29.39 & 32.84 & 30.82 & 28.30 & 27.50 & 26.20 \\
\hline an & 27.75 & 23.77 & 21.05 & 23.73 & 26.71 & 25.77 & 25.46 \\
\hline di & 27.83 & 28.05 & 28.19 & 26.54 & 24.48 & 26.97 & 27.11 \\
\hline hy & 8.21 & 8.59 & -- & 6.07 & 2.19 & 4.13 & 11.58 \\
\hline ol & 10.83 & 5.74 & 14.19 & 9.38 & 13.89 & 10.84 & 5.13 \\
\hline il & 1.65 & 2.87 & 2.92 & 2.84 & 2.65 & 2.65 & 2.57 \\
\hline $\mathrm{FeO}^{*} / \mathrm{MgO}$ & 1.15 & 1.66 & $\overline{1.64}$ & 1.57 & $\overline{1.61}$ & $\overline{1.63}$ & 1.63 \\
\hline \multicolumn{8}{|c|}{ Site 321} \\
\hline & \multicolumn{2}{|c|}{$14-1,42-45$} & $14-2,9-12$ & $14-3,7-10$ & \multicolumn{2}{|c|}{$14-4,7-10$} & $13-1,77-80$ \\
\hline $\mathrm{SiO}_{2}$ & \multicolumn{2}{|c|}{49.95} & 49.92 & 50.49 & \multicolumn{2}{|c|}{50.63} & 50.25 \\
\hline $\mathrm{TiO}_{2}$ & \multicolumn{2}{|c|}{2.18} & 2.34 & 2.39 & \multicolumn{2}{|c|}{2.44} & 1.23 \\
\hline $\mathrm{Al}_{2} \mathrm{O}_{3}$ & \multicolumn{2}{|c|}{12.86} & 12.82 & 12.85 & \multicolumn{2}{|c|}{12.90} & 15.79 \\
\hline $\mathrm{FeO} * \mathrm{a}$ & \multicolumn{2}{|c|}{13.26} & 12.68 & 13.30 & \multicolumn{2}{|c|}{13.10} & 8.34 \\
\hline $\mathrm{MgO}$ & \multicolumn{2}{|c|}{4.90} & 5.94 & 5.96 & \multicolumn{2}{|c|}{6.06} & 7.06 \\
\hline $\mathrm{CaO}$ & \multicolumn{2}{|c|}{10.39} & 11.44 & 9.77 & \multicolumn{2}{|c|}{9.99} & 13.55 \\
\hline $\mathrm{MnO}$ & \multicolumn{2}{|c|}{0.21} & 0.20 & 0.17 & \multicolumn{2}{|c|}{0.17} & 0.16 \\
\hline $\mathrm{Na}_{2} \mathrm{O}$ & \multicolumn{2}{|c|}{2.88} & 2.68 & 3.00 & \multicolumn{2}{|c|}{2.94} & 1.76 \\
\hline $\mathrm{K}_{2} \mathrm{O}$ & \multicolumn{2}{|c|}{0.11} & 0.16 & 0.16 & \multicolumn{2}{|c|}{0.21} & 0.14 \\
\hline Total & & $\overline{74}$ & $\overline{98.18}$ & $\overline{98.09}$ & & $\overline{.44}$ & $\overline{98.23}$ \\
\hline & & & Normative & omposition & & & \\
\hline$q$ & & - & -- & -- & & - & 0.71 \\
\hline or & & 69 & 0.99 & 0.99 & & .29 & 0.85 \\
\hline$a b$ & & 33 & 24.97 & 27.95 & & .29 & 16.17 \\
\hline an & & 08 & 23.33 & 21.92 & & .11 & 35.59 \\
\hline di & & 12 & 28.46 & 22.71 & & .31 & 26.57 \\
\hline hy & & 58 & 15.27 & 20.25 & & .96 & 18.39 \\
\hline ol & & - & 3.64 & 2.76 & & .57 & - \\
\hline il & & 21 & 3.39 & 3.46 & & .52 & 1.76 \\
\hline $\mathrm{FeO} * / \mathrm{MgO}$ & & 15 & 2.13 & 2.22 & & .15 & 1.17 \\
\hline
\end{tabular}

${ }^{\mathrm{a}}$ Total iron given as $\mathrm{FeO}^{*}$. 


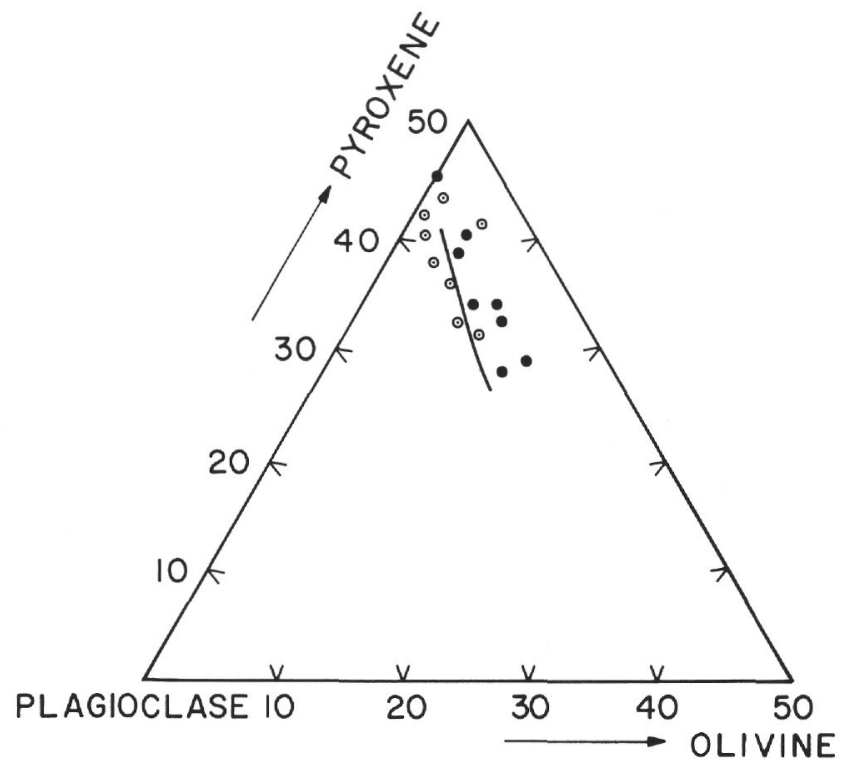

Figure 1. Normative olivine-plagioclase-pyroxene diagram. Filled circles represent Hole 319 analyses from Table 1. Open circles are same analyses after recalculation of sufficient $\mathrm{FeO}$ to $1.5 \mathrm{wt} \% \mathrm{Fe}_{2} \mathrm{O}_{3}$. Boundary represents cotectic curve (Shido et al., 1971).

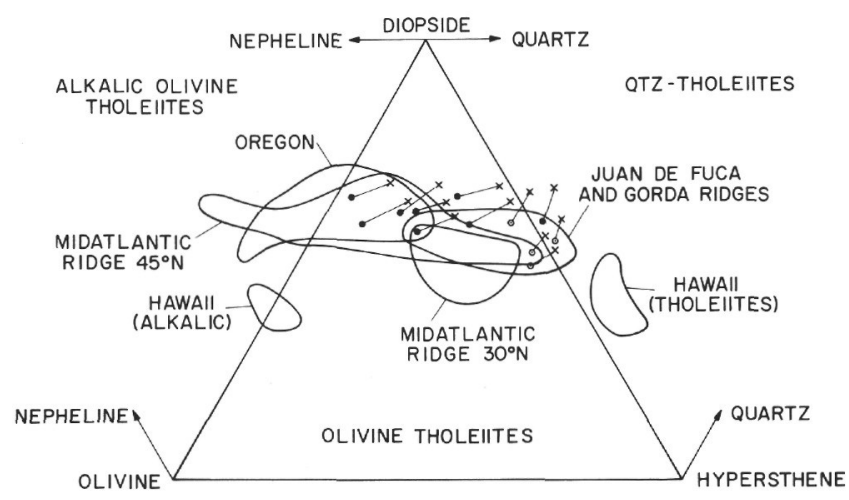

Figure 2. Normative mineralogy of'Oregon alkalic basalts (Snavely et al., 1968); Hawaiian basalts (MacDonald and Katsura, 1964); Mid-Atlantic Ridge $30^{\circ} \mathrm{N}$ and $45^{\circ} \mathrm{N}$ and Juan de Fuca and Gorda ridges (Kay et al., 1970); and Leg 34 basalts plotted on a diopside-hypersthene-olivinenepheline-quartz diagram. Filled circles are analyses from Table 1 (Site 319); $X$ are calculated with $1.5 \mathrm{wt} \% \mathrm{Fe}_{2} \mathrm{O}_{3}$. Open circles are analyses from Table 1 (Site 321).

$\mathrm{K}_{2} \mathrm{O}$ content is found in the most sodic varieties, although they rarely exceed $\mathrm{Or}_{4}$. Most samples contain very fine-grained (interstitial) material of $\mathrm{K}$-feldspar (Figure 4).

At least three generations of plagioclase were observed in most samples. Three samples (319A-2-1, 111-114 cm; 319A-3-5, 75-78 cm; and 319A-5-1, 20-22 cm) contain glomeroporphyritic phenocrysts of approximate core compositions of $\mathrm{An}_{\mathbf{8 4}}-\mathrm{An}_{\mathbf{8 1}}$ and rim compositions of $\mathrm{An}_{52}-$ An 19. A second generation of smaller laths $(<0.7-0.1$ $\mathrm{mm}$ ) are commonly ophitically or subophiticall enclosed in augite and have core compositions less calcic $\left(A n_{80}-A n_{62}\right)$ than phenocrysts. The range of composition
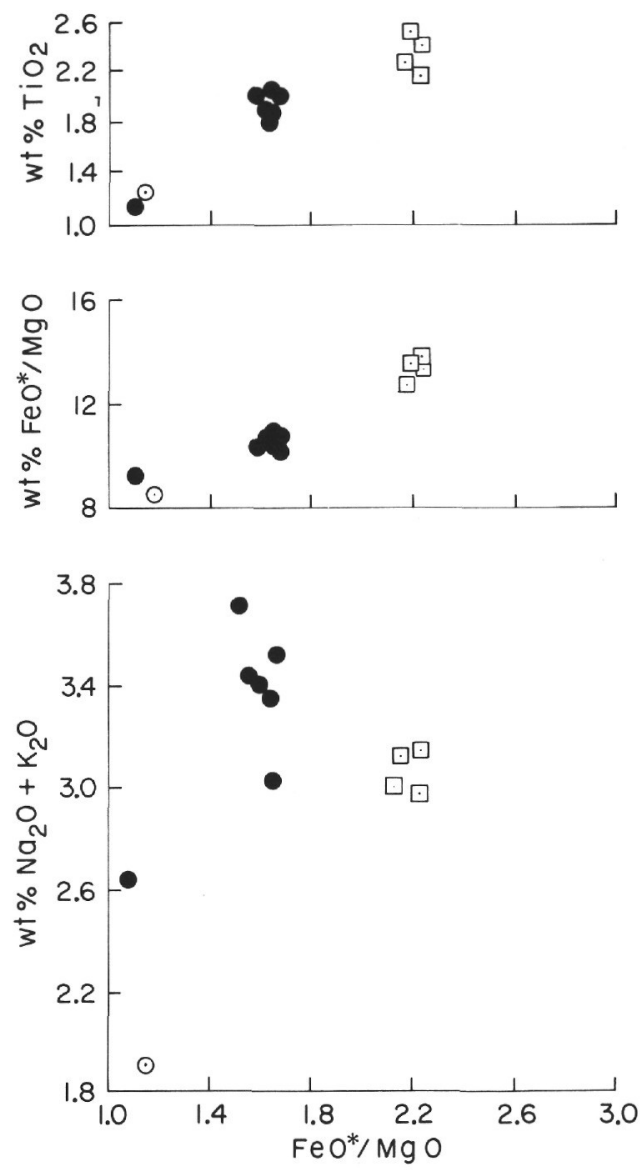

O HOLE 319

- HOLE 3I9A

口 HOLE 321

Figure 3. (a) Variation of $\mathrm{TiO}_{2}$ with $\mathrm{FeO} / \mathrm{MgO}$; (b) Variation of $\mathrm{FeO}^{*}$ with $\mathrm{FeO} / \mathrm{MgO}$; (c) Variation of alkalies with $\mathrm{FeO} * \mathrm{MgO}$.

laths nucleated later and ceased to grow earlier than the is always less than that of phenocrysts, indicating that phenocrysts. Groundmass plagioclase $(<0.1 \mathrm{~mm})$, present mostly as small radiating laths in variolitic bundles or in variably textured groundmass areas, are also zoned and overlapped in their crystallization time with the outer, sodic margins of the phenocrysts. Core compositions in two samples are $A n_{30}$, and $A n_{15}$ in a third, whereas the rims range from $A n_{15}$ to $A n_{7}$. Interstitial feldspar $(<0.01$ $\mathrm{mm}$ ) is present in $319 \mathrm{~A}-3-5,75-78 \mathrm{~cm}$ and varies in composition from $\mathrm{Or}_{46}$ to $\mathrm{Or}_{66}$. One sample (319A-6-1, 93-98 $\mathrm{cm}$ ) contains isolated phenocrysts of plagioclase with core compositions of $\mathrm{An}_{88}$, which is the most calcic composition found, and rim compositions of $\mathrm{An}_{55}$. The phenocrysts are set in a holocrystalline matrix of medium-grained to fine-grained plagioclase laths of narrow compositional range (core $\mathrm{An}_{57}$ to rim $\mathrm{An}_{52}$ ). Interstitial $\mathrm{K}$-feldspar is $\mathrm{Or}_{30}-\mathrm{Or}_{50}$. The remaining samples are ophitic to subophitic with complex variations in rapidly cooled variolitic textures. Two of these samples contain plagioclase of three generations (319A-3-1, 78-81 cm: phenocrysts, laths, groundmass-interstitial; and 319A-1-1, 48-51 cm: two distinct lath sizes and groundmass-interstitial). Phenocrysts or larger laths have a core composition of Anso. Smaller laths overlap them in crystallization time but are much less calcic (cores $\mathrm{An}_{58}-\mathrm{An}_{44}$ ). Groundmass laths do not 
SAMPLE

HOLE 319A
CORE

RIM

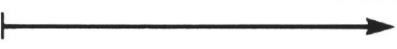

------1 INTERSTITIAL GROUNDMASS

$\vdash \rightarrow$ LATH

PHENOCRYST
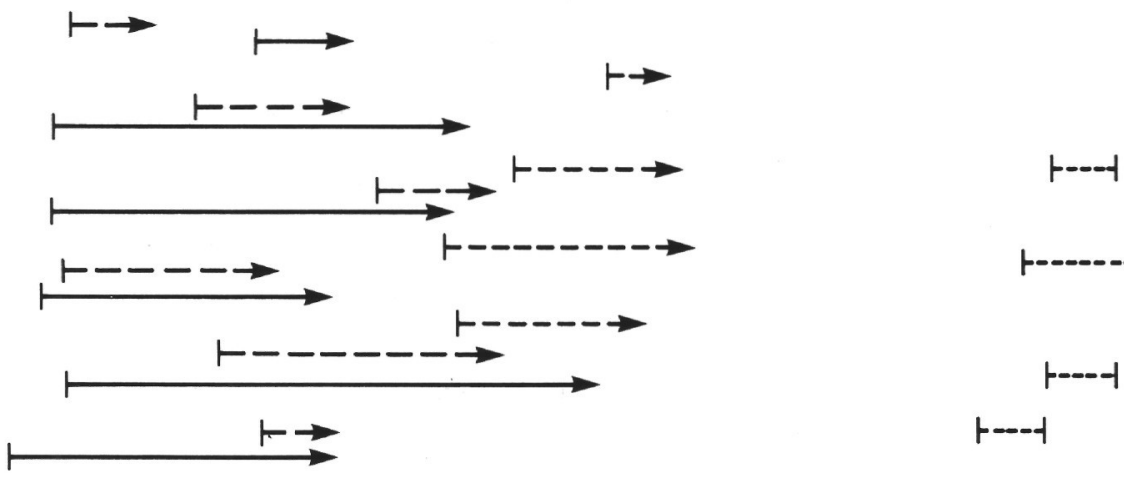

$\left.\begin{array}{c}3-1,78-81 \\ 3-5,75-78 \\ 5-1,20-22 \\ 6-1,93-98\end{array}\right]$

HOLE 319

$13-1,77-80$
$13-1,140-143$[

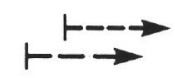

$1---1$
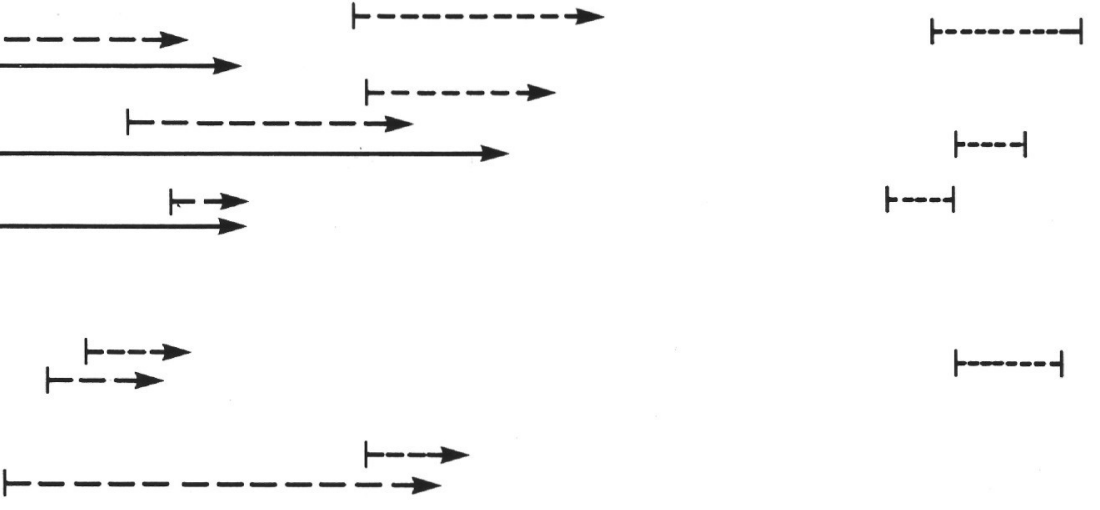

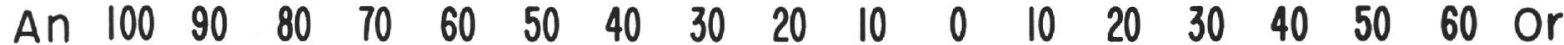

$\begin{array}{lllllllllllllllllll}\mathrm{Ab} & 0 & 10 & 20 & 30 & 40 & 50 & 60 & 70 & 80 & 90 & 100 & 90 & 80 & 70 & 60 & 50 & 40 & \mathrm{Ab}\end{array}$

Figure 4. Compositions of core to rim for plagioclase and interstitial feldspar.

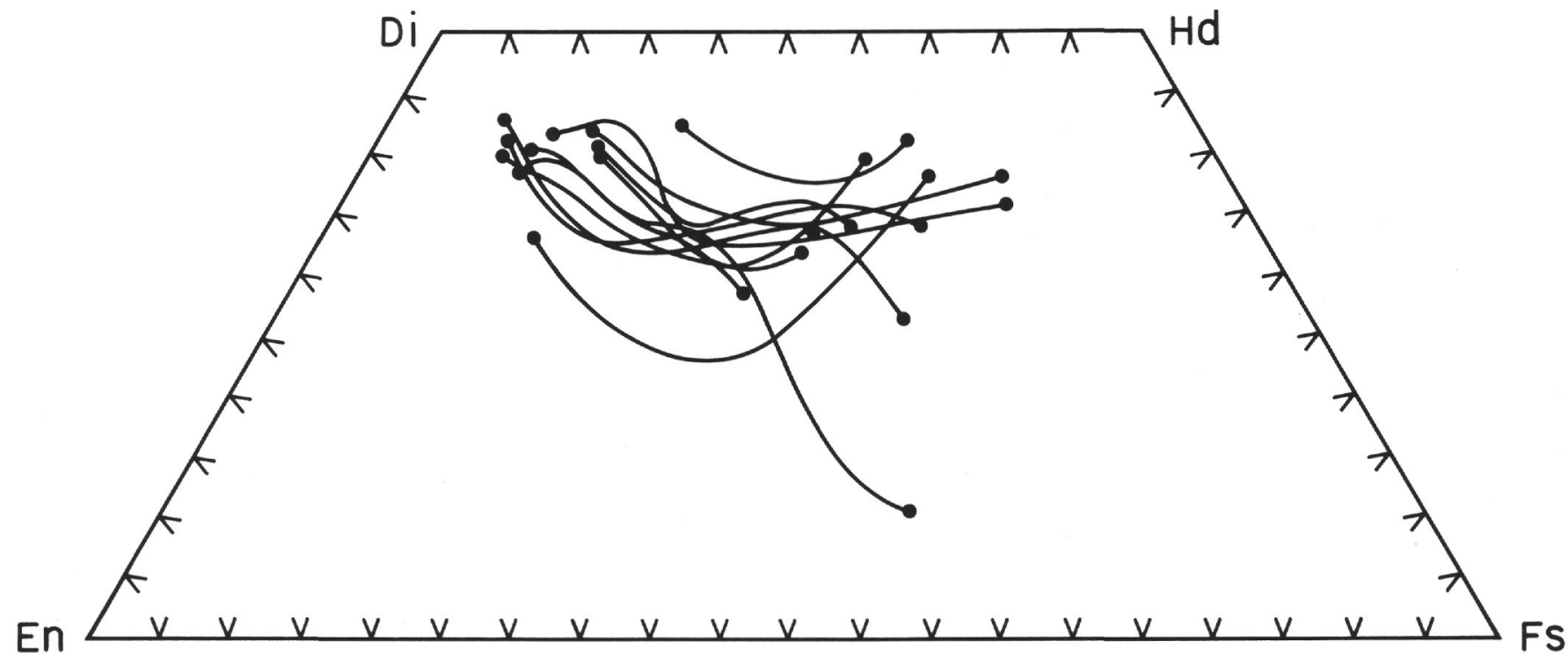

Figure 5. En-Di-Hd-Fs pyroxene quadrilateral showing pyroxene compositional trends of phenocryst and/or microphenocryst core through to groundmass or interstitial pyroxene (Holes 319A, 319, and Site 321).

samples contain laths that show an extreme range in composition from cores of $\mathrm{An}_{78}$ to rims of $\mathrm{An}_{30}$.

\section{Pyroxene}

All pyroxene, regardless of grain size, has some degree of compositional zoning. Phenocrysts were found in only two fine- to medium-grained samples; glomerocrysts in 319A-5-1, 20-22 cm and phenocrysts in 319A-6-1, 93-98 cm. Large anhedral augite with poikilitic second-generation plagioclase was observed in 319A-3-1, 78-81 cm. Microphenocrysts are ophitic to subophitic in relation to plagioclase, although two 


\section{- PHENOCRYST \\ - MICROPHENOCRYST \\ + GROUNDMASS}

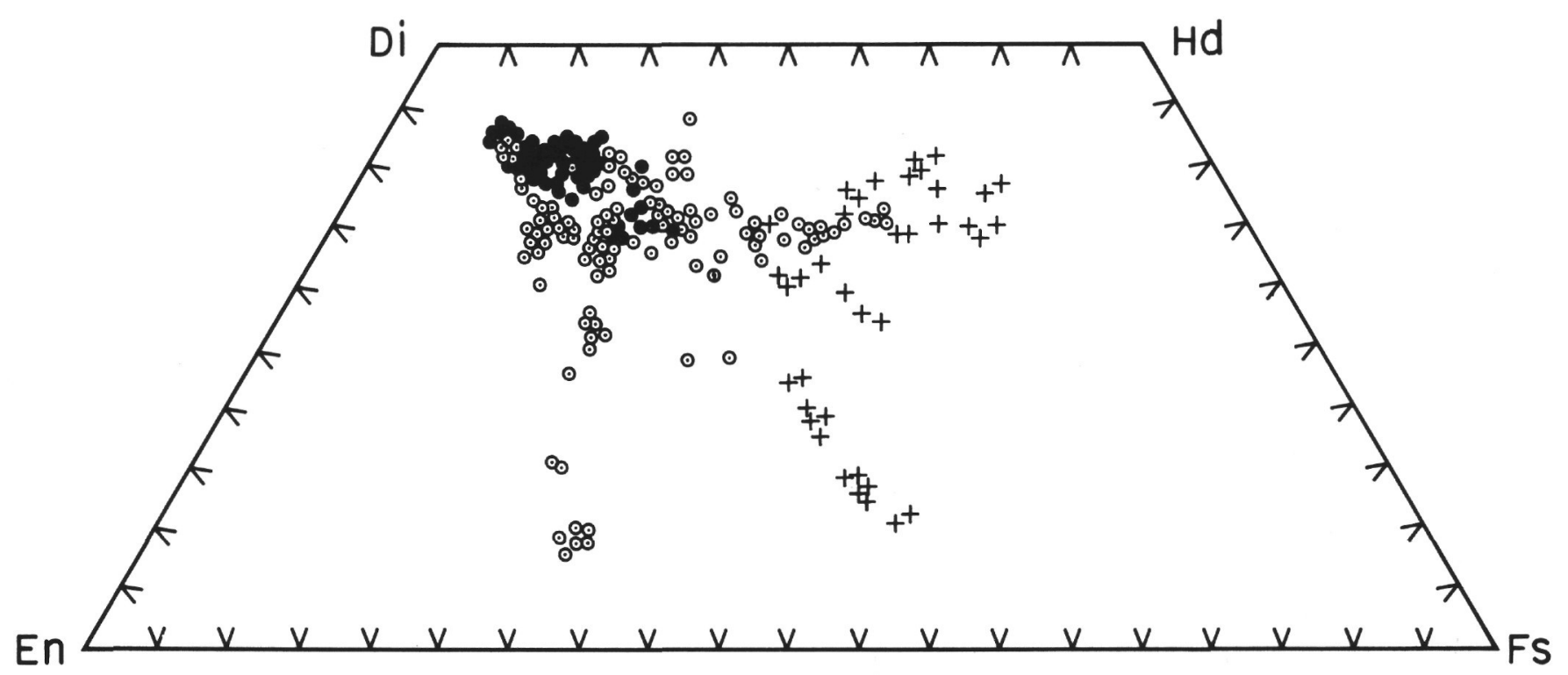

Figure 6. En-Di-Hd-Fs pyroxene quadrilateral showing total microprobe analyses of pyroxenes from Holes 319A, 319, Site 321, and one from Hole $320 B$ (subcalcic to pigeonite trend).
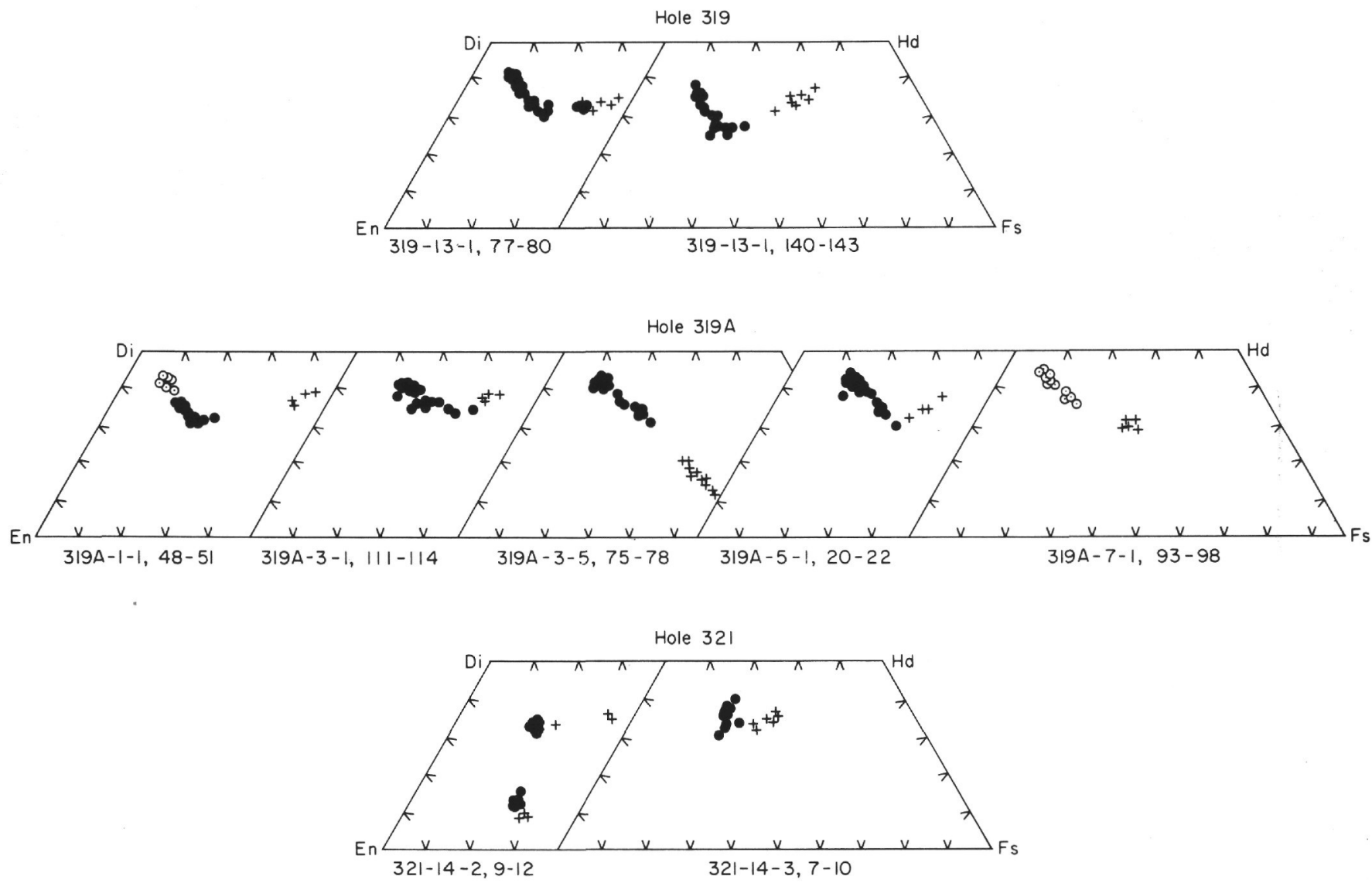

Figure 7. En-Di-Hd-Fs pyroxene quadrilateral showing representative pyroxene compositional trends for individual samples of Holes 319A, 319, and Site 321. 


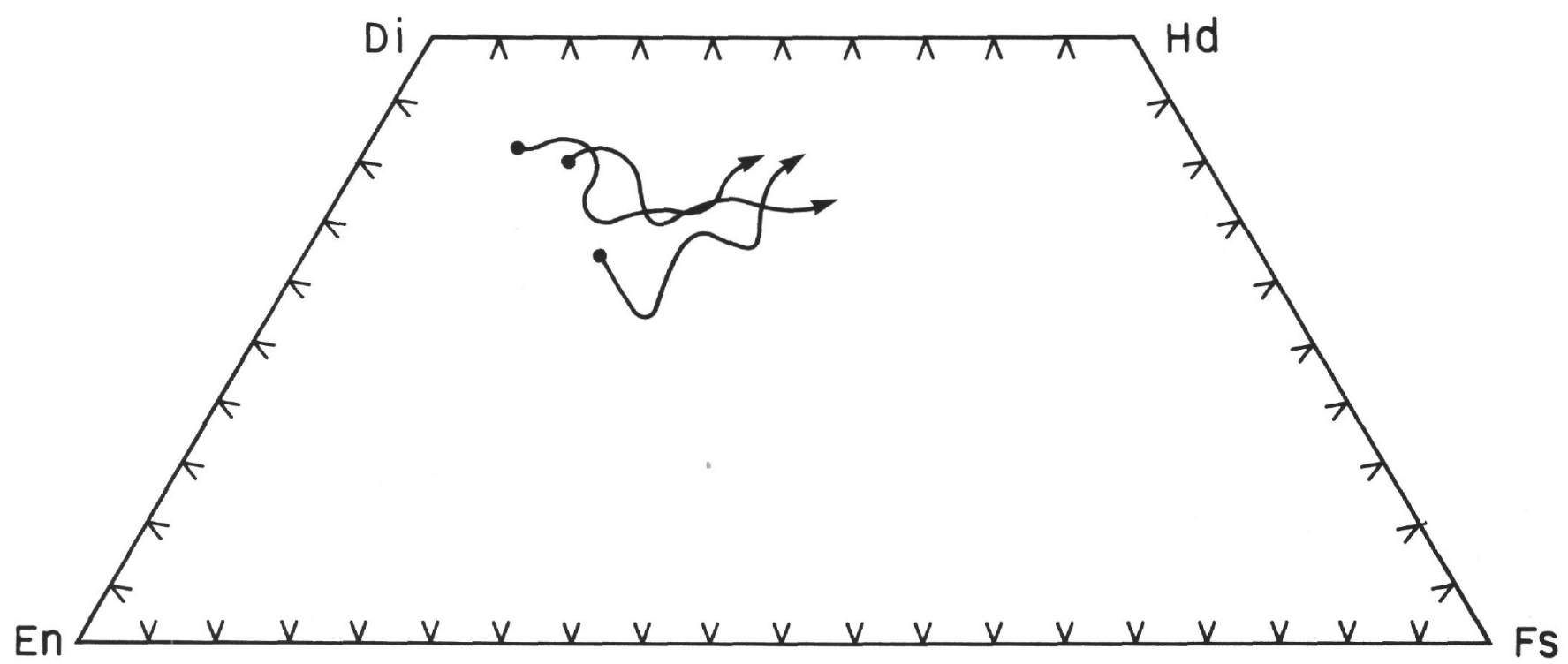

Figure 8. En-Di-Hd-Fs pyroxene quadrilateral showing compositional trends for coarse-grained phyric basalts (Hole 319A).

overlap and are very sodic $\left(\mathrm{An}_{27}-\mathrm{An}_{7}\right)$. Fine-grained samples contain intergranular pyroxene with respect to larger plagioclase. Groundmass pyroxene is very common in the variolitic textured areas. Interstitial pyroxene was found in all samples. Representative analyses according to textural type are given in Table 2 .

Microphenocrysts in 319A-1-1, 48-51 cm are the most magnesian pyroxene with core compositions of

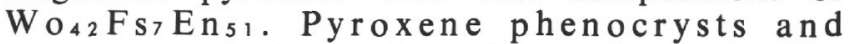
microphenocrysts are augite with groundmass pyroxene present as augite or ferroaugite. Interstitial pyroxene is ferroaugite.

Pyroxene in all samples shows an extreme range in composition from early-stage $\mathrm{Mg}$-rich augite to latestage ferroaugite (Figures 5, 6, and 7). Most samples contain pyroxene that show a Skaergaard crystallization trend in that there is $\mathrm{Ca}$ depletion with $\mathrm{Fe}$ enrichment until ferroaugite composition is reached in the outer margins of groundmass or interstitial pyroxene, where there is $\mathrm{Ca}$ enrichment with increasing iron content. The range of composition and the degree of differentiation for these pyroxenes are somewhat different from those of other oceanic basalts and Hawaiian-type basalts. One sample (319A-3-5, 77-78 cm) contains interstitial subcalcic ferroaugite (Figure 7). Sample 319-13-1, 140-143 $\mathrm{cm}$ shows a pyroxene crystallization trend that passes into the subcalcic augite compositional range in the $\mathrm{Fe}$ rich margins of microphenocrysts. A sample from Site $321(321-14-2,9-12 \mathrm{~cm})$ contains subcalcic augite of $\mathrm{Wo}_{12} \mathrm{Fs}_{30} \mathrm{En}_{58}$.

The three coarse-grained ophitic samples, listed in the Introduction, contain large $(2-7 \mathrm{~mm})$ ophitic augite with included plagioclase laths. Core compositions are not quite as magnesian as in the finer grained varieties (Table 3 and Figures 8 and 9), although rim compositions are less Fe rich. Smaller ophitic and groundmass augite pyroxene are also less $\mathrm{Fe}$ rich than their equivalents in the finer grained rocks. In addition, the pyroxene differentiation trend is different in that the $\mathrm{Ca}$ depletion dip is absent and the range is more limited
(Figure 8). The unusual variations seen in the trend lines could be attributed to the more complex sector zoning in the large ophitic grains.

Phenocryst and microphenocryst cores commonly contain $\approx 4$ wt $\% \mathrm{Al}_{2} \mathrm{O}_{3}$ (Table 2 and Figure 10), which decreases with increasing $\mathrm{FeO}$ content to $\approx 2 \mathrm{wt} \%$ in $\mathrm{Fe}$ rich rims; coexisting phenocrysts and microphenocrysts contain about the same amount of $\mathrm{Al}_{2} \mathrm{O}_{3}$ and show the same range of $\mathrm{Al}_{2} \mathrm{O}_{3}$ content. Cores of phenocrysts and microphenocrysts commonly contain more $\mathrm{TiO}_{2}$ than their rims, although groundmass pyroxene commonly contains higher $\mathrm{TiO}_{2}$ than larger grained pyroxene. Textural observations indicate that the main Ti-bearing phases, titanomagnetite and ilmenite, did not commence to crystallize until the bulk of pyroxene had formed.

\section{Opaque Minerals}

Homogeneous titanomagnetite is the dominant opaque phase in all samples studied with minor amounts of sulfide (not analyzed) in most samples and ilmenite in two samples (analyses of titanomagnetite and ilmenite are given in Table 4).

Titanomagnetite occurs as anhedral to skeletal grains that are rarely larger than $0.1 \mathrm{~mm}$. It is commonly found in groundmass areas and is particularly enriched in altered glass patches. It reaches its maximum grain size in the coarse-grained phyric basalts in the 15.6-meter unit.

Composition of titanomagnetite is fairly homogeneous among all of the samples; $\mathrm{TiO}_{2}$ varies from a minimum of $20.6 \mathrm{wt} \%$ to a maximum of $23.2 \mathrm{wt} \%$. Minor elements ( $\mathrm{Al}, \mathrm{Mg}, \mathrm{Mn})$ show little variation. Coexisting ilmenite, when present, seems to have a tendency for slightly higher contents of $\mathrm{MnO}$ and $\mathrm{Al}_{2} \mathrm{O}_{3}$ and less $\mathrm{MgO}$ than coexisting titanomagnetite. The distribution of $\mathrm{Mn}$ between these two phases is consistent with data of Buddington and Lindsley (1964) for basaltic and gabbroic rocks.

Titanomagnetite and ilmenite analyses were recalculated into ideal end members by following the 
TABLE 2

Representative Microprobe Analyses of Phenocrysts, Microphenocrysts, and Groundmass Pyroxene Cores and Average Analyses of Interstitial Pyroxene from Site 319

\begin{tabular}{|c|c|c|c|c|c|c|c|c|c|c|c|c|c|}
\hline \multicolumn{14}{|c|}{ Sample (Interval in $\mathrm{cm}$ ) } \\
\hline & \multicolumn{4}{|c|}{$319 A-1-1,48-51$} & \multicolumn{2}{|c|}{$319 A-2-1,111-114$} & \multicolumn{4}{|c|}{$319 \mathrm{~A}-3-1,78-81$} & \multicolumn{3}{|c|}{$319 A-3-5,75-78$} \\
\hline & 1 & 2 & 3 & 4 & 2 & 3 & 1 & 2 & 3 & 4 & 2 & 3 & 4 \\
\hline $\mathrm{SiO}_{2}$ & 51.5 & 50.7 & 51.4 & 52.2 & 50.2 & 50.5 & 51.7 & 51.9 & 51.8 & 51.6 & 51.5 & 52.4 & 52.2 \\
\hline $\mathrm{Al}_{2} \mathrm{O}_{3}$ & 4.0 & 4.2 & 2.28 & 1.45 & 3.78 & 1.96 & 3.95 & 2.28 & 1.87 & 1.05 & 3.38 & 1.31 & 0.78 \\
\hline $\mathrm{TiO}_{2}$ & 0.81 & 1.02 & 1.24 & 1.12 & 1.65 & 1.20 & 1.20 & 0.71 & 1.16 & 0.83 & 1.13 & 1.01 & 0.68 \\
\hline $\mathrm{FeO} * \mathrm{a}$ & 5.6 & 9.0 & 13.0 & 25.2 & 9.7 & 20.2 & 7.4 & 12.4 & 15.8 & 24.4 & 7.5 & 8.1 & 25.8 \\
\hline $\mathrm{MgO}$ & 17.5 & 17.1 & 16.2 & 4.7 & 14.1 & 9.8 & 15.4 & 14.4 & 12.5 & 9.8 & 16.1 & 16.2 & 12.2 \\
\hline $\mathrm{CaO}$ & 19.7 & 17.0 & 14.8 & 15.9 & 19.5 & 15.1 & 19.7 & 17.1 & 15.8 & 11.4 & 19.9 & 19.4 & 7.0 \\
\hline Total b & $\overline{99.11}$ & $\overline{99.02}$ & $\overline{98.92}$ & $\overline{100.57}$ & $\overline{99.50}$ & $\overrightarrow{98.76}$ & $\overline{99.35}$ & $\overrightarrow{98.79}$ & $\overline{98.93}$ & $\overline{99.09}$ & $\overline{99.51}$ & $\overline{98.42}$ & 99.66 \\
\hline Wo & 40.7 & 35.6 & 31.2 & 37.8 & 41.8 & 33.9 & 42.0 & 36.5 & 34.7 & 25.9 & 41.3 & 40.2 & 15.0 \\
\hline Fs & 9.0 & 14.7 & 21.4 & 46.7 & 16.2 & 35.4 & 12.3 & 20.7 & 27.1 & 43.2 & 12.2 & 13.1 & 45.6 \\
\hline \multirow[t]{3}{*}{ En } & 50.2 & 49.8 & 47.4 & 15.5 & 42.0 & 30.6 & 45.7 & 42.8 & 38.2 & 30.1 & 46.5 & 46.7 & 39.4 \\
\hline & \multicolumn{4}{|c|}{$319 A-5-1,20-22$} & \multicolumn{3}{|c|}{$319 A-6-1,93-98$} & \multicolumn{3}{|c|}{$319-13-1,77-80$} & \multicolumn{3}{|c|}{$319-13-1,140-143$} \\
\hline & 1 & 2 & 3 & 4 & 1 & 3 & 4 & 2 & 3 & 4 & 2 & 3 & 4 \\
\hline $\mathrm{SiO}_{2}$ & 51.1 & 42.9 & 50.8 & 51.6 & 51.8 & 51.6 & 52.8 & 53.0 & 50.1 & 53.3 & 52.5 & 52.7 & 52.1 \\
\hline $\mathrm{Al}_{2} \mathrm{O}_{3}$ & 3.86 & 2.81 & 2.82 & 0.96 & 3.26 & 3.20 & 1.30 & 1.65 & 3.81 & 1.13 & 2.61 & 2.26 & 1. \\
\hline $\mathrm{TiO}_{2}$ & 1.27 & 0.99 & 1.54 & 0.80 & 0.64 & 0.67 & 0.58 & 0.33 & 1.06 & 1.01 & 0.54 & 0.87 & 1.40 \\
\hline $\mathrm{FeO}^{*}$ & 9.6 & 11.6 & 17.5 & 20.2 & 6.2 & 8.7 & 19.2 & 6.0 & 18.2 & 18.5 & 8.5 & 14.5 & 22.9 \\
\hline $\mathrm{MgO}$ & 16.0 & 13.6 & 11.7 & 8.3 & 17.5 & 16.7 & 11.3 & 17.0 & 10.8 & 9.5 & 17.8 & 15.5 & 6.2 \\
\hline $\mathrm{CaO}$ & 17.2 & 17.1 & 15.0 & 17.3 & 19.5 & 18.0 & 13.6 & 20.3 & 15.6 & 15.4 & 17.6 & 13.3 & 16.4 \\
\hline Total & $\overline{99.03}$ & $\overline{99.00}$ & $\overline{99.36}$ & $\overline{99.16}$ & $\overline{98.90}$ & $\overline{98.87}$ & 98.78 & $\overline{98.28}$ & $\overline{99.57}$ & $\overline{98.84}$ & $\overline{99.95}$ & $\overline{99.13}$ & 100.66 \\
\hline Wo & 36.6 & 37.9 & 33.3 & 38.8 & 40.8 & 39.0 & 30.7 & 42.0 & 34.8 & 35.8 & 35.9 & 27.8 & 38.2 \\
\hline Fs & 16.0 & 20.1 & 30.4 & 35.3 & 10.3 & 12.9 & 33.8 & 9.5 & 31.7 & 33.5 & 13.5 & 21.6 & 41.7 \\
\hline En & 47.4 & 42.0 & 36.3 & 25.9 & 48.9 & 48.1 & 35.5 & 48.5 & 33.5 & 30.7 & 50.6 & 50.6 & 20.1 \\
\hline
\end{tabular}

Note: Analysis 1 is phenocryst or large microphenocryst, analysis 2 is microphenocryst, analysis 3 is groundmass, and analysis 4 is interstitial pyroxene.

a All Fe reported as $\mathrm{FeO}^{*}$.

$\mathrm{b}_{\mathrm{MnO} \text { and }} \mathrm{Cr}_{2} \mathrm{O}_{3}$ not analyzed.

methods of Buddington and Lindsley (1964) and Anderson (1968). These calculations, on the average, give an ulvöspinel (Usp) content of 63 for titanomagnetite and a hematite $(\mathrm{Hm})$ content of 6 for ilmenite. These values give an $\mathrm{fO}_{2}$ of $10^{-14.7}$ and $\mathrm{T}$ of $840^{\circ} \mathrm{C}$ when interpreted according to the $\mathrm{fO}_{2}-\mathrm{T}$ graphs of Buddington and Lindsley (1964), and appear to be appropriate for lateformed minerals.

\section{Other Minerals}

Olivine was found only in Sample 319A-6-1, 93-98 cm as microphenocrysts. Microprobe analyses give an average composition of $\mathrm{SiO}_{2}, 40.8 ; \mathrm{FeO}, 16.3 ; \mathrm{MgO}$, 42.5; and $\mathrm{CaO}, 0.28$ wt\%. Compositional range varies between $\mathrm{Fo}_{84-81}$.

Very small $(<0.015 \mathrm{~mm})$ anhedral opaque grains of unusual compositions were found in the groundmass of Sample 319-13-1, 77-80 cm. These moderately reflective grains, which are tan colored in reflected light, contain variable amounts of $\mathrm{Si}, \mathrm{Al}, \mathrm{V}, \mathrm{Ti}, \mathrm{Mn}$, and $\mathrm{Fe}$. One grain has a V-rich margin with up to 19 wt\% V. Three analyzed grains give the following compositions in elemental wt\%. Grain 1: Si, 30-37; Ti, 0.53-12.5; Mn, 1.0-1.9; and $\mathrm{Fe}, 40.4-42.7$. Grain 2: $\mathrm{Si}, 26-38 ; \mathrm{Ti}, 0.3-17.4 ; \mathrm{Mn}$, 0.8-2.1; Ge, 30.2-36.7. Grain 3: Si, 27-32; V, 24-26.7; Al, 5.7-6.9; $\mathrm{Ti}, 4.2-7.6$; and $\mathrm{Fe}, 4.0-6.1$. No $\mathrm{P}, \mathrm{S}$, or $\mathrm{O}$ were detected. Carbon cannot be measured adequately because the samples are carbon coated, although microprobe results show much higher readings for these grains relative to their surroundings. We have excluded contamination as a possible source. Since these grains are found only in slightly altered portions of the sample, it could be that they formed during alteration under low temperature and low $\mathrm{fO}_{2}$.

\section{INDIVIDUAL SAMPLE DESCRIPTIONS}

\section{A-1-1, 48-51 cm}

Texture: Medium grained, ophitic intergranular to variolitic. Plagioclase was the first mineral to crystallize; 
TABLE 3

Representative Microprobe Analyses of Ophitic Pyroxene in Coarse-Grained Rocks

\begin{tabular}{|c|c|c|c|c|c|c|c|}
\hline \multicolumn{8}{|c|}{ Sample (Interval in $\mathrm{cm}$ ) } \\
\hline & \multicolumn{2}{|c|}{$319 A-3-1,80-82$} & \multicolumn{2}{|c|}{$319 A-3-2,84-86$} & \multicolumn{3}{|c|}{$319 A-3-3,64-67$} \\
\hline & $1^{\mathrm{a}}$ & $2^{b}$ & 1 & 2 & 1 & 2 & 3 \\
\hline $\mathrm{SiO}_{2}$ & 53.0 & 52.1 & 52.9 & 52.3 & 51.2 & 51.75 & 52.2 \\
\hline $\mathrm{Al}_{2} \mathrm{O}_{3}$ & 2.09 & 2.39 & 3.20 & 2.86 & 3.06 & 2.22 & 1.76 \\
\hline $\mathrm{TiO}_{2}$ & 1.01 & 1.80 & 1.02 & 1.53 & 1.13 & 0.86 & 0.76 \\
\hline $\mathrm{FeO}^{*}$ & 9.4 & 12.6 & 7.6 & 11.1 & 13.0 & 16.81 & 18.6 \\
\hline $\mathrm{MgO}$ & 14.7 & 14.0 & 17.2 & 16.2 & 16.5 & 12.610 & 10.8 \\
\hline $\mathrm{CaO}$ & 19.2 & 18.3 & 19.0 & 17.0 & 14.9 & 15.21 & 16.3 \\
\hline Total & $\overline{99.40}$ & $\overline{101.19}$ & $\overline{100.92}$ & $\overline{100.99}$ & $\overline{99.79}$ & $\overline{99.381}$ & $\overline{100.42}$ \\
\hline Wo & 41 & 38 & 39 & 35 & 31 & 33 & 36 \\
\hline Fs & 16 & 21 & 12 & 18 & 21 & 29 & 32 \\
\hline En & 43 & 41 & 49 & 47 & 48 & 38 & 32 \\
\hline
\end{tabular}

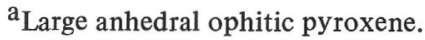

$\mathrm{b}_{\mathrm{Groundmass}}$ pyroxene.

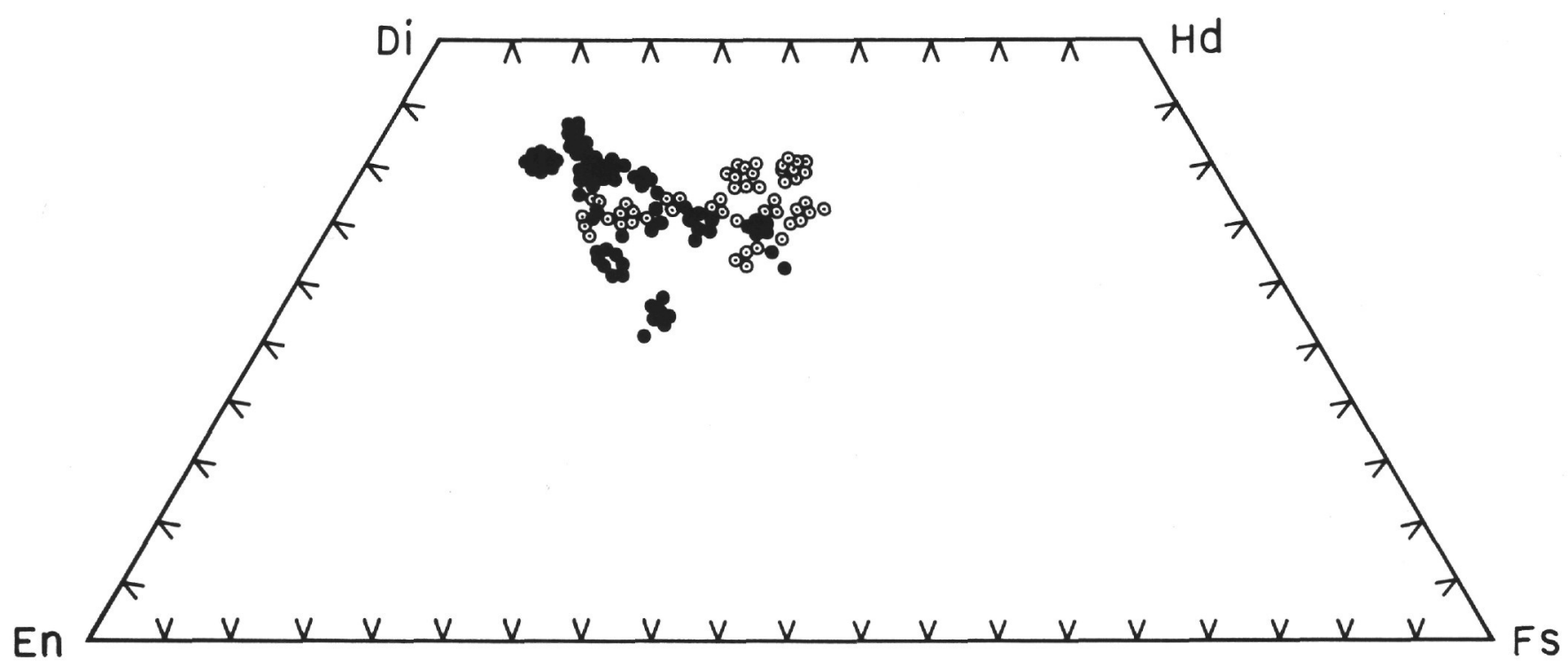

Figure 9. Microprobe analyses for ophitic pyroxene core to rim (filled circles) and groundmass (open circles).

lath dimensions range from $1-2 \mathrm{~mm}$ to $0.1 \mathrm{~mm}$; microphenocrysts are $<0.1 \mathrm{~mm}$ and are common in radiating, variolitic sheaths of pyroxene plagioclase. Pyroxene phenocrysts range in size from 0.4 to $0.2 \mathrm{~mm}$; microphenocrysts range from 0.2 to $0.04 \mathrm{~mm}$ and groundmass pyroxene is $<0.04$ to $0.02 \mathrm{~mm}$. The opaque mineral is titanomagnetite, which is $<0.1 \mathrm{~mm}$ in diameter. Smectite pseudomorphs of olivine are common and some K-rich patches are present in the groundmass.

Plagioclase: Large laths $(>0.4 \mathrm{~mm})$ have core composition of $A_{81}$ with slight zoning to the margins with rim composition of $A_{75}$. The smaller laths, particularly those in variolitic areas, have core composition of $\mathrm{An}_{57}$ and rim composition of $\mathrm{An}_{47}$. Groundmass plagioclase is only slightly more sodic $\left(\mathrm{An}_{45}-\mathrm{An}_{42}\right)$. Interstitial "feldspar" is probably glass although the composition is nearly stoichiometric for K-feldspar.

Pyroxene: The small pyroxene (augite) phenocrysts are slightly zoned from $\mathrm{WO}_{43} \mathrm{Fs}_{7} \mathrm{En}_{50}$ to $\mathrm{WO}_{40} \mathrm{Fs}_{11} \mathrm{En}_{40}$. Microphenocrysts range from core composition of $\mathrm{Wo}_{36} \mathrm{Fs}_{14} \mathrm{E}_{50}$ to rims of $\mathrm{Wo}_{33} \mathrm{Fs}_{24} \mathrm{En}_{43}$. Tiny grains $(<0.01 \mathrm{~mm})$ of interstitial pyroxene (ferroaugite) are very iron rich and the average composition is $\mathrm{Wo}_{38} \mathrm{Fs}_{46} \mathrm{En}_{16}$ (see Figure 7).

\section{9-2-1, 111-114 cm}

Texture: Glomeroporphyritic plagioclase, ophitic with intergranular pyroxene. Round to ovoid amygdules of secondary minerals $(0.5-1.2 \mathrm{~mm}$ diameter $)$ are ran- 
SAMPLE

HOLE 319A
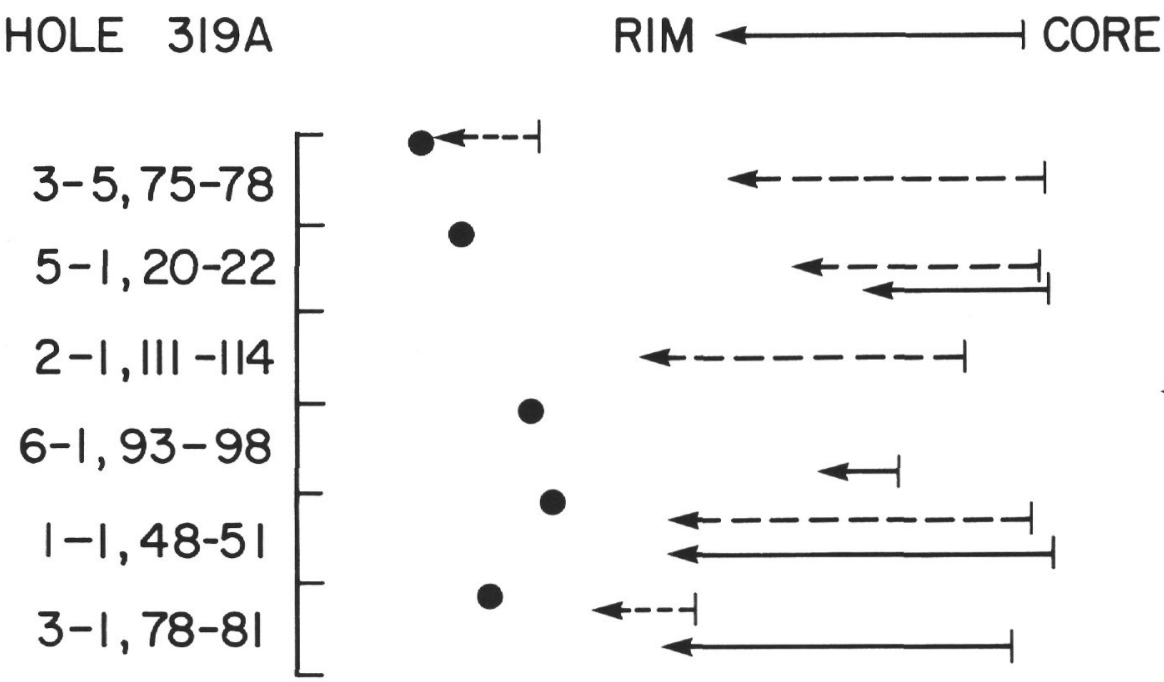

\section{- INTERSTITIAL $\leftarrow--\dashv$ GROUNDMASS $\leftarrow-$ MICROPHENOCRYST $\longleftarrow$ PHENOCRYST}

HOLE 319

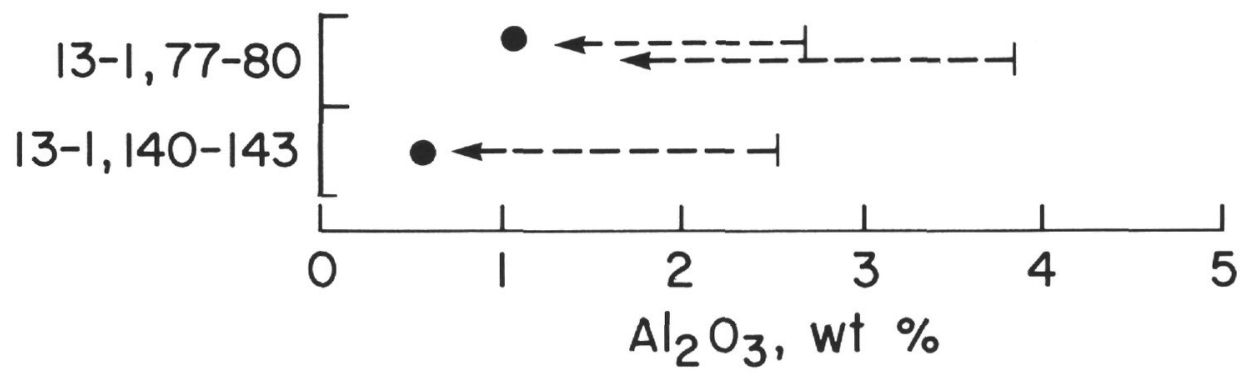

Figure 10. $\mathrm{Al}_{2} \mathrm{O}_{3}$ content (core to rim) of pyroxene from Hole 319.

TABLE 4

Electron Microprobe Analyses of Titanomagnetite and Ilmenite From Site 319

\begin{tabular}{lcccccc}
\hline $\begin{array}{c}\text { Sample } \\
\text { (Interval in cm) }\end{array}$ & $\mathrm{TiO}_{2}$ & $\mathrm{FeO}^{* a}$ & $\mathrm{Al}_{2} \mathrm{O}_{3}$ & $\mathrm{MgO}$ & $\mathrm{MnO}$ & Total \\
\hline Titanomagnetite & & & & & & \\
319A-1-1, 48-51 & 20.6 & 71.8 & 2.00 & 0.34 & 0.60 & 95.34 \\
$319 \mathrm{~A}-1-1,78-79$ & 21.5 & 68.6 & 2.97 & 0.97 & 0.34 & 94.38 \\
$319 \mathrm{~A}-2-1,111-114$ & 21.8 & 68.1 & 2.00 & 0.50 & 0.64 & 93.04 \\
319A-3-1, 78-81b & 21.9 & 71.0 & 2.32 & 0.55 & 0.53 & 96.30 \\
319A-3-1, 80-82 & 20.9 & 70.5 & 3.10 & 0.61 & 0.56 & 95.67 \\
$319 \mathrm{~A}-3-2,84-86$ & 22.4 & 69.7 & 3.34 & 0.53 & 0.55 & 96.52 \\
$319 \mathrm{~A}-3-3,64-67 \mathrm{~b}$ & 21.4 & 70.8 & 3.25 & 0.35 & 0.57 & 96.37 \\
$319 \mathrm{~A}-5-1,20-22$ & 23.2 & 67.6 & 2.25 & 0.57 & 0.57 & 94.19 \\
& & & & & & \\
Ilmenite & & & & & & \\
$319 \mathrm{~A}-3-1,78-81^{\mathrm{b}}$ & 46.9 & 47.7 & 4.2 & 0.39 & 0.66 & 99.85 \\
319A-3-3, 64-67b & 48.0 & 47.6 & 3.01 & 0.31 & 0.66 & 99.58 \\
\hline
\end{tabular}

${ }^{a} \mathrm{All} F e$ reported as $\mathrm{FeO}^{*}$.

${ }^{b}$ Coexisting pairs.

domly distributed. Plagioclase glomerocrysts are 0.6-1.4 $\mathrm{mm}$ and laths range from 0.1 to $1.2 \mathrm{~mm}$. Smaller laths tend to be skeletal with ragged edges and lath crosssections tend to have hollow cores. Intergranular pyroxene grains are small $(<0.15 \mathrm{~mm})$. Titanomagnetite grains are anhedral equant to elongate in shape and are less than $0.12 \mathrm{~mm}$ in size. Modal analysis: ( $\Sigma$ plagioclase includes all textural forms) $\Sigma$ plagioclase, $48 \%$; glomerocrysts, $8.0 \%$; pyroxene, $32 \%$; opaques, $5 \%$; finegrained interstitial material and secondary minerals, $7 \%$. 
Plagioclase: Glomerocryst core composition is $\mathrm{An}_{82-}$ $\mathrm{An}_{76}$ with outer margin zoning mostly continuous to $\mathrm{An}_{34}$. Lath composition is limited in range $\left(\mathrm{An}_{65}-\mathrm{An}_{48}\right)$. Groundmass plagioclase $(<0.1 \mathrm{~mm})$ composition is $\mathrm{An}_{15}-\mathrm{An}_{12}$

Pyroxene: Intergranular grains are zoned from $\mathrm{WO}_{40} \mathrm{Fs}_{17} \mathrm{En}_{43}$ to $\mathrm{WO}_{35} \mathrm{Fs}_{30} \mathrm{En}_{35}$. Groundmass pyroxene $(<0.05 \mathrm{~mm})$ has an average composition of $\mathrm{WO}_{35} \mathrm{Fs}_{34} \mathrm{E}_{34}$. This sample shows the narrowest compositional range for pyroxene of all the analyzed samples (see Figure 7).

\section{A-3-1, 78-81 cm}

Texture: Coarse-grained ophitic with variolitic sheaves with radiating clusters of pyroxene and plagioclase. In addition, there are evenly spaced intersertal areas containing poorly crystallized "quenched" material, skeletal plagioclase, high opaque concentration, Fe-rich pyroxene, silica, and K-feldspar. Large plagioclase laths are $0.7-2 \mathrm{~mm}$. Smaller laths are 0.08-0.7 $\mathrm{mm}$. Large pyroxene is $0.8-1.4 \mathrm{~mm}$ and uncommon; microphenocryst pyroxene is $0.1-0.3 \mathrm{~mm}$; groundmass pyroxene is $<0.05 \mathrm{~mm}$. Opaques are blocky titanomagnetite and skeletal ilmenite $(0.03-0.3 \mathrm{~mm})$ and minor sulfides. Modal analysis: plagioclase, 44\%; pyroxene, $38 \%$; opaques, $5 \%$; intersertal material, $13 \%$.

Plagioclase: Large plagioclase laths show extensive zoning, $\mathrm{An}_{82}-\mathrm{An}_{37}$, confined mostly to the outer margins. Microphenocrysts and smaller distinct laths overlap in crystallization time with the most sodic lath zones and have a rather limited compositional range of $\mathrm{An}_{44-}-\mathrm{An}_{31}$. Groundmass plagioclase is $\mathrm{An}_{37}-\mathrm{An}_{7}$. Most microphenocrysts are present in radiating clusters of plagioclase and pyroxene.

Pyroxene: Ophitic pyroxene phenocrysts are augite of average composition $\mathrm{Wo}_{42} \mathrm{Fs}_{13} \mathrm{En}_{45}$. No overlap in composition of phenocrysts and microphenocrysts was found; microphenocryst compositions range from $\mathrm{Wo}_{38} \mathrm{Fs}_{22} \mathrm{En}_{40}$ to $\mathrm{Wo}_{33} \mathrm{Fs}_{35} \mathrm{En}_{32}$. Groundmass and interstitial pyroxene show a trend toward Fe-rich compositions and less calcic compared to other samples where the last pyroxene stage tends to be Fe rich, but more calcic compositions as does Sample 319A-3-5, 75$78 \mathrm{~cm}$ (see Figure 7).

\section{A-3-1, 80-82}

Texture: Coarse-grained phyric basalt with variable and complex groundmass, ranging from subophitic to variolitic. The texture is more adequately described as poikilophitic where the overall ophitic texture is characterized by lath-shaped plagioclase grains completely enclosed in large subhedral to anhedral pyroxene grains. Plagioclase phenocrysts are subhedral and range in size from 1.5 to $3 \mathrm{~mm}$. Groundmass laths and enclosed laths are $0.2-2.5 \mathrm{~mm}$. Ophitic pyroxene is abundant and ranges in size from 2 to $7 \mathrm{~mm}$; groundmass pyroxene, 0.05 $0.4 \mathrm{~mm}$. Opaque mineral content is high and is present as equant to skeletal grains $(0.01-0.2 \mathrm{~mm})$. Numerous interstitial patches of fine-grained, poorly crystallized pyroxene, plagioclase, and opaques are associated with large amounts of alteration minerals.

Plagioclase: Phenocryst core to rim compositions range from $A_{n}$ to $A_{n 43}$; microphenocryst core to rim compositions are from $\mathrm{An}_{54}$ to $\mathrm{An}_{37}$; groundmass plagioclase ranges from $\mathrm{An}_{19}$ to $A n_{10}$.

Pyroxene: Ophitic cores are fairly homogeneous; $\mathrm{Fe}$ enrichment is prevalent only toward margins. Pyroxene core compositions are given in Table 3. Analyses for the three coarse-grained samples are shown in Figures 8 and 9. Ophitic pyroxene compositions trend towards the Fs corner with constant depletion of Wo, whereas microphenocrysts show a cross-trending nature towards Hd, with a nearly constant Wo content. These observations, together with compositional gaps between ophitic pyroxene and microphenocryst, suggest a separate, distinct crystallization period for microphenocrysts.

\section{A-3-2, 84-86 cm}

Texture: Coarse-grained phyric basalt with variable groundmass, ranging from subophitic to variolitic. Similar to Sample 319A-3-1, 80-82 cm, although variolitic groundmass is present. Poikilophitic with lathshaped plagioclase completely enclosed in large anhedral pyroxene. Plagioclase phenocrysts are subhedral to lath shaped and range in size from 1.5 to 3.0 $\mathrm{mm}$; microphenocrysts are $0.08-1.2 \mathrm{~mm}$. Groundmass plagioclase is $0.05-0.3 \mathrm{~mm}$. Plagioclase phenocrysts have inclusions of plagioclase microphenocrysts at the margins. Ophitic pyroxene is $1.0-4.0 \mathrm{~mm}$; microphenocrysts are $0.06-0.9 \mathrm{~mm}$. Opaques are blocky to anhedral and are $<0.15 \mathrm{~mm}$ in diameter. Intersertal areas of poorly crystallized minerals plus altered glass are numerous.

Plagioclase: Core to rim phenocryst compositions range from $A_{60}$ to $A n_{41}$, microphenocrysts from $A_{n_{52}}$ to $\mathrm{An}_{24}$, and groundmass from $\mathrm{An}_{28}$ to $\mathrm{An}_{18}$. Laths included in pyroxene have a very narrow compositional range (core to rim) of $\mathrm{An}_{50}-\mathrm{An}_{47}$, which suggests that pyroxene nucleated later, but overlapped with plagioclase phenocryst growth.

Pyroxene: Similar to $319 \mathrm{~A}-3-1,80-82 \mathrm{~cm}$.

\section{A-3-3, 64-67 cm}

Texture: Coarse-grained phyric basalt, with subophitic granular groundmass. Very similar to 319A-3-2, $84-86 \mathrm{~cm}$, with the exceptions that no variolitic areas are present, and interstitial areas are filled with alteration minerals. Plagioclase phenocrysts are $1.2-2 \mathrm{~mm}$; microphenocryst laths are $0.2-1.5 \mathrm{~mm}$; ophitic pyroxene is $2-7 \mathrm{~mm}$; microphenocrysts are $0.05-0.4 \mathrm{~mm}$. Opaque minerals are commonly larger than in other samples $(0.005-0.7 \mathrm{~mm})$ and are blocky to skeletal in shape.

Plagioclase: Phenocrysts show a wide compositional range from core to rim of $\mathrm{An}_{72}$ to $\mathrm{An}_{23}$; microphenocrysts from $\mathrm{An}_{60}$ to $\mathrm{An}_{20}$ (those in pyroxene, $\left.A n_{59}-\mathrm{An}_{53}\right)$; groundmass, $\mathrm{An}_{43}-\mathrm{An}_{16}$. Interstitial $\mathrm{K}$ feldspar is $\mathrm{Or}_{37} \mathrm{Ab}_{61} \mathrm{An}_{2}$.

Pyroxene: Similar to $319 \mathrm{~A}-3-1,80-82 \mathrm{~cm}$.

\section{A-3-5, $75-78 \mathrm{~cm}$}

Texture: Glomeroporphyritic with subophitic matrix. Plagioclase is glomerocrystic and the first to crystallize; size range $0.5-1.8 \mathrm{~mm}$. Subophitic plagioclase laths are $0.08-0.6 \mathrm{~mm}$, and groundmass plagioclase is $<0.08 \mathrm{~mm}$. All plagioclase is zoned. Pyroxene microphenocrysts 
range in size from 0.06 to $0.25 \mathrm{~mm}$; groundmass pyroxene 0.06-0.02 mm. Numerous smectite pseudomorphs after olivine are common. Opaque minerals are blocky to skeletal in form and are $<0.07 \mathrm{~mm}$ in size. $\mathrm{K}$-feldspar interstitial grains are common. Modal analyses: $\Sigma$ plagioclase, $48 \%$; phenocrysts, $6 \%$; pyroxene, $39 \%$; and opaques, $7 \%$.

Plagioclase: Glomerocrysts have a range in composition from core $A_{85}$ to rim $A_{52}$. Small matrix laths $\left(A n_{81}-A n_{58}\right)$ overlap entirely with glomerocrysts, which are both more calcic and sodic (Figure 4). Groundmass plagioclase is quite separated from the two larger generations; varying in composition from core $\mathrm{An}_{35}$ to $\operatorname{rim} \mathrm{An}_{7}$.

Pyroxene: Microphenocrysts are zoned from core composition of $\mathrm{Wo}_{40} \mathrm{Fs}_{12} \mathrm{En}_{48}$ to rims of $\mathrm{Wo}_{34} \mathrm{Fs}_{26} \mathrm{En}_{40}$. Groundmass pyroxene overlaps microphenocrysts in composition with cores $\mathrm{Wo}_{40} \mathrm{Fs}_{13} \mathrm{En}_{4}$ to rims of about the same composition. Interstitial grains are extremely $\mathrm{Fe}$ rich and subcalcic, ranging from $\mathrm{Wo}_{22} \mathrm{FS}_{39} \mathrm{En}_{39}$ to $\mathrm{Wo}_{11} \mathrm{Fs}_{53} \mathrm{En}_{36}$ (see Figure 7).

\section{A-5-1, 20-22 cm}

Texture: Glomeroporphyritic with subophitic intergranular to variolitic groundmass. Variolitic areas have altered glass and high concentrations of opaque minerals. Ovoid patches of carbonate are common. Plagioclase glomerocrysts range from 0.6 to $1.2 \mathrm{~mm}$, laths from 0.1 to $1.3 \mathrm{~mm}$, and groundmass from 0.03 to $0.1 \mathrm{~mm}$. Pyroxene included in plagioclase glomerocrysts and are less numerous, ranging in size from 0.4 to 0.9 $\mathrm{mm}$. Microphenocrysts are 0.07-0.15 mm. Titanomagnetite is commonly skeletal or rod shaped and $0.005-0.3 \mathrm{~mm}$ in size. Modal analysis: $\Sigma$ plagioclase, $42 \%$; phenocrysts, $4 \%$; pyroxene, $45 \%$; opaques, $3 \%$; and interstitial material, $6 \%$.

Plagioclase: Glomerocrysts show the widest range in composition from core, $\mathrm{An}_{81}$ to rim, $\mathrm{An}_{19}$, of all the samples analyzed. Matrix laths have narrower compositional range, core $\mathrm{An}_{61}$ to $\mathrm{rim} \mathrm{An}_{31}$. Groundmass plagioclase overlaps both glomerocrysts and laths; core $\mathrm{An}_{34}$ to rim $\mathrm{An}_{16}$.

Pyroxene: Large grains included within plagioclase glomerocrysts have core compositions of $\mathrm{WO}_{40} \mathrm{Fs}_{17} \mathrm{En}_{43}$ to rim compositions of $\mathrm{Wo}_{30} \mathrm{Fs}_{30} \mathrm{En}_{40}$. Compositions change continuously from these and microphenocryst cores and rims to interstitial Fe-rich pyroxene (see Figure 7).

\section{$319 A-6-1,93-98 \mathrm{~cm}$}

Texture: Porphyritic with holocrystalline groundmass, which is pilotaxitic due to flow orientation of small groundmass plagioclase laths $(0.04-0.3 \mathrm{~mm})$. Phenocrysts consist of euhedral to subhedral plagioclase $(0.3-1.2 \mathrm{~mm})$ which are zoned and augite $(0.3-0.6 \mathrm{~mm})$. Rare, small (0.03-0.7 mm) pyroxene grains are also present. Opaque minerals are extremely rare and very small $(<0.02 \mathrm{~mm})$. Interstitial material is altered glass and alteration minerals. Modal analysis: $\Sigma$ plagioclase, $37 \%$; phenocrysts, 6\%; pyroxene phenocrysts, $7 \%$; microphenocrysts, $8 \%$; opaques, $2 \%$; fine-grained interstitial material, $40 \%$.
Plagioclase: Cores of phenocrysts are the most calcie of all plagioclase analyzed (An\&9); rims are $\mathrm{An}_{50}$. Groundmass laths are only slightly zoned, showing a range in composition from $\mathrm{An}_{57}$ to $\mathrm{An}_{52}$.

Pyroxene: Phenocrysts cores are $\mathrm{W}_{040} \mathrm{Fs}_{10} \mathrm{En}_{50}$ with rims of $\mathrm{WO}_{35} \mathrm{FS}_{20} \mathrm{En}_{45}$. The fine-grained groundmass pyroxene is Fe-rich $\left(\mathrm{WO}_{31} \mathrm{FS}_{35} \mathrm{En}_{36}\right)$ and is quite different in composition from the phenocrysts in that no continuous compositional zoning from phenocrysts to groundmass pyroxene exists which is distinctly different from the case in other samples. This may suggest a gap in crystallization of the intratelluric and posteruptive stages.

\section{PERTINENT OBSERVATIONS AND SUMMARY}

1. Our basalt samples are characterized by plagioclase, clinopyroxene, and opaque mineral assemblages that commonly show evidence of at least late-stage rapid cooling as indicated by the presence of plagioclase and pyroxene varioles of various types and intersertal textures. Mineral compositions, together with textural observations suggest a sequence of early-formed calcic plagioclase and/or augite phenocrysts (when present) followed and overlapped by more fractionated microphenocrysts that finally gave way to rapidly cooled groundmass. Pyroxenes show extensive fractionation from Mg-augite phenocryst cores to ferroaugite groundmass/interstitial pyroxene. In addition they show a trend of $\mathrm{Ca}$ depletion with $\mathrm{Fe}$ enrichment in the middle stages to $\mathrm{Ca}$ enrichment with further $\mathrm{Fe}$ enrichment in the late-stage fraction. Coarse-grained phyric rocks contain large poikilitic pyroxene with mostly unoriented plagioclase inclusions. Pyroxenes in these coarse-grained rocks are less fractionated than and show different trends from those in finer-grained samples.

2. All analyzed samples are hypersthene-low-quartz or low-olivine normative (saturated) tholeiites based on an assumed $1.5 \mathrm{Fe}_{2} \mathrm{O}_{3}$ wt\% content and correspond to typical oceanic tholeiites (Engel and Engel, 1964). Compared with the average "abyssal" tholeiites of Engel and Engel, Leg 34 basalts differ compositionally in high amounts of $\mathrm{SiO}_{2}, \mathrm{FeO}^{*}, \mathrm{TiO}_{2}$, and $\mathrm{Na}_{2} \mathrm{O}$ contents and lower $\mathrm{MgO}$, with $\mathrm{K}_{2} \mathrm{O}$ and $\mathrm{P}_{2} \mathrm{O}_{5}$ about the same; all samples have $<0.36 \mathrm{wt} \% \mathrm{~K}_{2} \mathrm{O}$.

3. Among our analyzed samples, $319 \mathrm{~A}-1-1,48-51 \mathrm{~cm}$, and $319-13-1,77-80 \mathrm{~cm}$ are the least fractionated, having the highest mafic (CI) and lowest felsic (DI) contents (Figure 11). Moreover, they contain lowest amounts of $\mathrm{TiO}_{2}, \mathrm{MnO}$, and $\mathrm{FeO}$; the highest amounts of $\mathrm{Al}_{2} \mathrm{O}_{3}$, $\mathrm{CaO}$, and $\mathrm{MgO}$; and the lowest $\mathrm{FeO}^{*} / \mathrm{MgO}$ ratios.

4. Basalts from Site 321 show marked fractionation compared with those from Site 319 in having higher $\mathrm{FeO}^{*} / \mathrm{MgO}$ ratios (2.15-2.70), higher $\mathrm{FeO}^{*} / \mathrm{MgO}$ versus $\mathrm{TiO}_{2}$ ratios, lower $\mathrm{Al}_{2} \mathrm{O}_{3}$ contents, and lower mafic components $(\mathrm{CI})$.

5. The above data and observations are consistent with shallow, low-P differentiation (Kay et al., 1970), controlled by olivine and plagioclase fractionation. Moreover, all rocks were apparently derived from a common parental source. Additional study of these 
rocks may show that pyroxene fractionation may also have played an important role as olivine is scarce in most of these rocks and had probably already been removed before crystallization of the individual flows.

\section{REFERENCES}

Anderson, A.T., 1968. Oxidation of the La Blache Lake titaniferous magnetite deposit, Quebec: J. Geol., v. 76, p. 528-547.

Buddington, A.F. and Lindsley, D.H., 1964. Iron-titanium oxide minerals and synthetic equivalents: J. Petrol., v. 5, p. 310-357.

Coombs, D.S., 1963. Trends and affinities of basaltic magmas and pyroxenes as illustrated on the diopside-olivine-silica diagram: Mineral. Soc. Am. Spec. Paper 1, p. 227.

Engel, A.E.J. and Engel, C.G., 1964. Composition of basalts from the Mid-Atlantic Ridge: Science, v. 144, p. 13301333.

Hekinian, R., 1974. Petrology of the Ninety East Ridge: Contrib. Mineral. Petrol., v. 43, p. 125-145.

Kay, R., Hubbard, N.J., and Gast, P., 1970. Chemical characteristics and origin of oceanic ridge volcanic rocks: J. Geophys. Res., v. 75, p. 1581-1613.

MacDonald, G.A. and Katsura, T., 1964. Chemical composition of Hawaiian lavas: J. Petrol., v. 5, p. 82-133.

Shido, F., Miyashiro, A., and Ewing, M., 1971. Crystallization of abyssal tholeiites: Contrib. Mineral. Petrol., v. 31, p. 251-266.

Snavely, P.D., MacLeod, U.S., and Wagner, H.C., 1968. Tholeiitic and alkalic basalts of the Eocene Siletz River volcanics, Oregon coast range: Am. J. Sci., v. 266, p. 454.

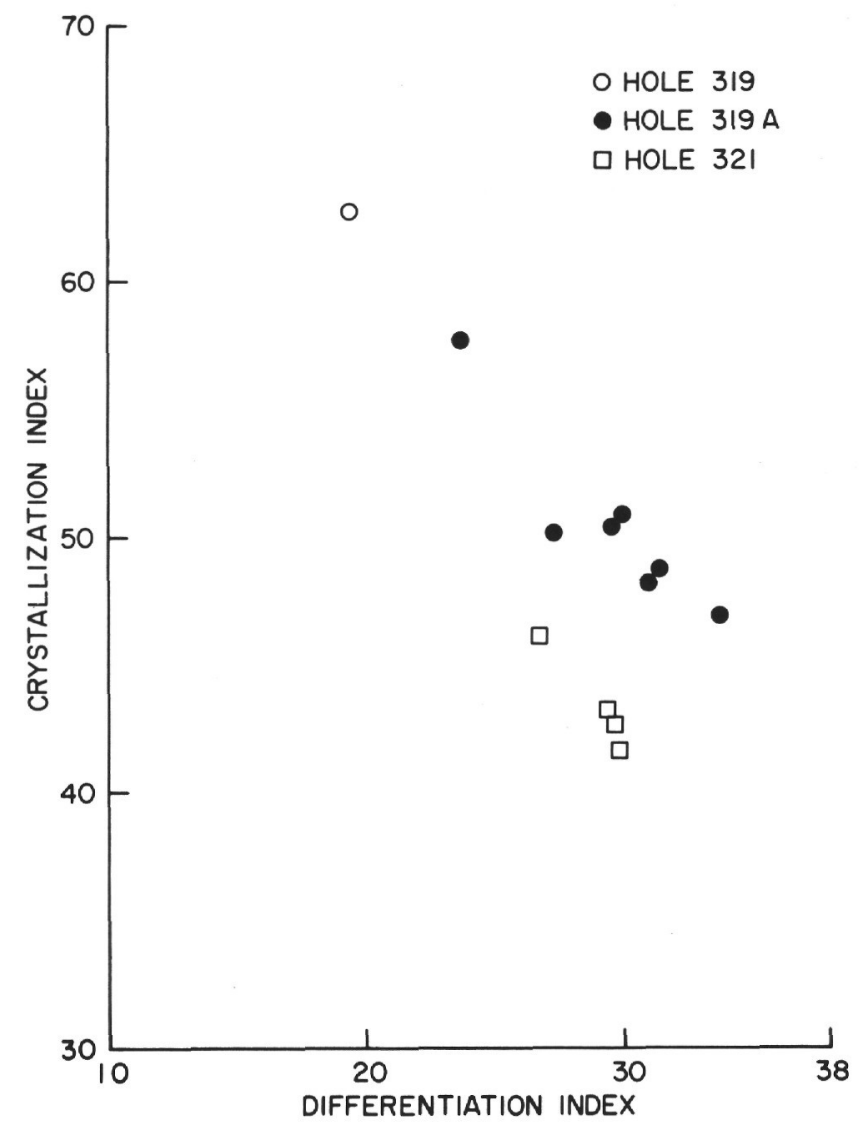

Figure 11. Crystallization index (CI) versus differentiation index (DI) for analyses from Table 1. Symbols same as for Figure 3. 